Original Article

\title{
ISOLATION AND CHARACTERIZATION OF POTENTIAL PROBIOTICS FROM FERMENTED RAGI (ELEUSINE CORACANA)
}

\author{
PRISCILLA MERCY ANITHA D. ${ }^{a}$, PERIYAR SELVAM S. ${ }^{\text {* }}$, SEEMA A. KULKARNIa
}

aDepartment of Biotechnology, SRM Institute of Science and Technology, Kattankulathur 603203, Tamil Nadu, India, bDepartment of Food and Process Engineering, SRM Institute of Science and Technology, Kattankulathur 603203, Tamil Nadu, India

Email: periyar.india@gmail.com

Received: 28 Feb 2018 Revised and Accepted: 15 May 2018

ABSTRACT

Objective: The aim of this study was to isolate, characterize and identify the potential lactic acid bacteria from fermented ragi millet (Eleusine coracana).

Methods: A total of 177 isolates were isolated from the fermented ragi porridge. All the isolates were subjected to preliminary screening (Gram staining and catalase test). The physiological features of the probiotic isolates such as tolerance to $\mathrm{pH}(2.0,4.0)$, phenol $(0.3 \%, 0.5 \%)$ and bile salt $(0.3 \%)$ were carried out. Antibiotic susceptibility test was performed using disc diffusion method. Free radical scavenging assay was conducted by 2,2-diphenyl-1-picrylhydrazyl (DPPH) method. The isolates were further characterized for their cholesterol-lowering property. Based on their survival ability and biochemical tests, the selected potent isolates were identified by $16 \mathrm{~S}$ rRNA gene sequence by PCR and phylogenetic analysis. The 16S rRNA gene sequencing confirmed that isolates were Lactococcus lactis RS01, Lactobacillus plantarum RS09, Lactobacillus plantarum RS16 and Lactobacillus plantarum RS23.

Results: Twenty five isolates were screened from the 177 total isolates based on their morphological and biochemical characteristics (Gram staining and catalase test). All the isolates showed tolerance against acid, phenol and bile salts. However, RS09 and RS23 exhibited maximum viable count and demonstrated good tolerance at the end of $3 \mathrm{~h}$. Highest antioxidant activity was recorded in RS09 ranging from 32-85\%. Among the tested strains, the degradation rate of supernatants, RS09 (61.9\%), RS23 (60\%) and RS01 (58.97\%) and RS16 (56.2\%) showed the highest cholesterol assimilation rate. In addition, they also found to be resistant and sensitive to few antibiotics.

Conclusion: Based on the obtained results, these isolates are ideal in vitro probiotic strains and can be used further for in vivo evaluation.

Keywords: Ragi, Fermentation, Probiotics, Acid tolerance, Bile tolerance, Antibiotic sensitivity, DPPH

(c) 2018 The Authors. Published by Innovare Academic Sciences Pvt Ltd. This is an open access article under the CC BY license (http://creativecommons.org/licenses/by/4.0/) DOI: http://dx.doi.org/10.22159/ijpps.2018v10i6.25565

\section{INTRODUCTION}

Probiotics are live microorganisms, which, when administered in adequate amounts, confer a health benefit on the host. Probiotic fermented foods are now being recognized and perceived as health foods. Most of the probiotic foods that are produced now are based on dairy products however extensive research work is also available on coarse cereals and millets, which constitute the staple foods in developing countries like India. Sorghum and pearl millet are usually ground into flour and consumed either as roti or porridge with milk or it can also be prepared as beverages [1]. The probiotic potential of lactic acid bacteria from traditional fermented foods are well documented [2-5]. Lactic acid bacteria (LAB) are generally Grampositive, non-spore forming, catalase-negative bacteria that are devoid of cytochromes and are of aero-tolerant, fastidious, acid tolerant and absolutely fermentative; lactic acid is the major endproduct of sugar fermentation [6]. Lactobacilli produce various antimicrobial compounds such as bacteriocins which are a highly specific antibacterial protein that prevents food from spoilage and provide additional protection against many harmful pathogens like Bacillus, Staphylococcus aureus and Clostridial spores in canned foods. Lactic acid bacteria particularly Lactobacillus, Lactococcus, Streptococcus, Pediococcus and Leuconostoc (beneficial and nonpathogenic genera) are widely used in various fermentations [7]. LAB are considered as "generally recognized as safe" (GRAS) organisms and can be safely used for medical and veterinary applications [8]. The criteria for the in vitro selection of lactobacilli to be considered as health-promoting, probiotic ingredients, in several food and pharmaceutical preparations include antibiotic tolerance and also the production of an active compound, lactic acid which inhibits the growth of other microorganisms; allow them to be established in the intestinal tract [9]. Moreover, there is a great expectation that probiotic bacteria should still be alive at a certain population number during the passage through gastrointestinal tract before it gets attached to the host lower intestinal tract and colon [10].

The objective of this study was to characterize the potential probiotics from the fermented ragi millet through acid and bile salts resistance, tolerance to phenol, and also to evaluate its antibiotic sensitivity towards the isolated strains, to check its ability to assimilate cholesterol and also to determine its antioxidant properties.

\section{MATERIALS AND METHODS}

\section{Chemicals and reagents}

All the chemicals used were of analytical grade and procured from Sigma Chemical Co., St. Louis, Mo, USA, Hi-Media, Mumbai, India and Southern India Scientific Corporation, Chennai, India.

\section{Sample collection}

A pack of ragi millet seeds (Eleusine coracana) were bought from the local supermarket at Maraimalai Nagar, Chennai, Tamil Nadu, India. The ragi millet seed identification was authenticated by taxonomist Dr. M. Kumar from Madras Christian College, Chennai, Tamilnadu, India. A voucher specimen was deposited in Postharvest Research Laboratory, SRM Institute of Science and Technology, Kattankulathur, Tamilnadu, India with a Voucher No: PRLRS1.

\section{Sample preparation}

Ragi millet seeds were washed and ground into fine powder and sieved to remove the husk. Two samples were prepared, wherein the first sample was prepared by mixing ragi powder with water and cooked for $10 \mathrm{~min}$ and the second sample was prepared by adding water and $5 \%$ starch to the ragi powder and cooked for $10 \mathrm{~min}$. Both 
the samples were allowed to ferment for 24 and $48 \mathrm{~h}$ and the $\mathrm{pH}$ was measured at 0,24 and $48 \mathrm{~h}$.

\section{Isolation of probiotic strains}

Samples were diluted serially to 10 -fold and then inoculated on de Man, Rogosa and Sharpe (MRS) agar plates by pour plate method. MRS agar plates were incubated at $37{ }^{\circ} \mathrm{C}$ for $48 \mathrm{~h}$ anaerobically. Morphologically distinct colonies were picked and transferred to new MRS agar plates by streaking. Finally, pure colonies were obtained after repeated subcultures and preserved for further study.

The isolates were preliminarily screened through Gram staining characteristics (Gram-positive), catalase test (-) and cell morphology examination (Bergey's manual of systematic bacteriology).

\section{Determination of in vitro characteristics of probiotics}

\section{Resistance to $\mathrm{pH}$}

Method of Gilliland [11] was performed. Active cultures were incubated in a shaker for $16-18 \mathrm{~h}$ in MRS broth at $37^{\circ} \mathrm{C}$. Tolerance of isolated strains to acidic $\mathrm{pH}$ was determined by growing bacteria in acidic MRS broth. MRS broth was prepared and sterilized. Separately, pH 2.0 and 4.0 was adjusted with $1 \mathrm{M} \mathrm{HCl}$ and $0.5 \mathrm{M}$ $\mathrm{NaOH}$. Isolated strains were inoculated in MRS broth separately. All the tubes were incubated at $37{ }^{\circ} \mathrm{C}$ and viable counts were determined by pour plate technique at every one hour gap for $3 \mathrm{~h}$. And the plates were incubated at $37^{\circ} \mathrm{C}$ under anaerobic condition for $48 \mathrm{~h}$. Survival cell counts were expressed as log values of colonyforming units per $\mathrm{ml}(\mathrm{CFU} / \mathrm{ml})[12]$.

\section{Resistance to bile salt}

The method of Gilliland [11] was followed. Strains were grown in MRS broth at $37{ }^{\circ} \mathrm{C}$ overnight and saturated bile solution was prepared separately by dissolving powdered bile extract at a concentration of $0.3 \%$ and without bile, served as control. The isolates were inoculated and incubated at $37^{\circ} \mathrm{C}$ for $3 \mathrm{~h}$ and then for every one-hour viable counts were determined by pour plate method. The plates were incubated at $37{ }^{\circ} \mathrm{C}$ under anaerobic conditions for $48 \mathrm{~h}$. Survival cell counts were expressed as log values of colony-forming units per $\mathrm{ml}(\mathrm{CFU} / \mathrm{ml}$ ) [12].

\section{Phenol tolerance test}

The phenol tolerance of the bacterial isolates was assessed by using the protocols [15] with slight modifications. MRS broth was modified with $0.3 \%$ and $0.5 \%$ phenol to determine the phenol tolerance of the isolates. The overnight cultures (1\%) of the isolates were inoculated into the freshly prepared MRS broth containing $0.3 \%$ and $0.5 \%$ phenol. After $3 \mathrm{~h}$ of incubation at $37^{\circ} \mathrm{C}$, OD was recorded at $600 \mathrm{~nm}$ [16]. The relative growth of the isolates was calculated using the following formula.

$$
\text { Relative growth }(\%)=\frac{A_{(\text {control })}-A_{(\text {sample })}}{A_{(\text {control })}} \times 100
$$

\section{Antibiotic sensitivity test}

Strains were evaluated for their susceptibility to antibiotics according to the technical guidelines of the European Food Safety Authority [13]. Antibiotics such as ampicillin, gentamicin, kanamycin, streptomycin, erythromycin and tetracycline were used. After culturing the isolates in MRS broth for $16 \mathrm{~h}$, they were swabbed on Mueller Hinton (MH) agar plates and incubated at $37^{\circ} \mathrm{C}$ for 24-48 $\mathrm{h}$. The zone of inhibition was observed.

\section{Cholesterol assimilation test}

The ability of the isolates to assimilate cholesterol was determined by a modified method described by Danielson et al. [14]. Each freshly prepared strain culture (cell-free extract) was inoculated (1\%) in MRS broth containing a water-soluble form of cholesterol from the cholesterol kit (ROBONIK, India Pvt. Ltd). The strains were incubated at $37^{\circ} \mathrm{C}$ for $1 \mathrm{~h}$. After one hour of incubation, the cultures were read at OD $600 \mathrm{~nm}$. The efficiency of the isolates to assimilate cholesterol was calculated.

$$
\text { Cholesterol assimilated }(\%)=\frac{A_{(\text {control })}-A_{(\text {sample })}}{A_{(\text {control })}} \times 100
$$

\section{DPPH radical scavenging activity}

DPPH method was performed to analyze the antioxidant (stability of 2,2-diphenyl-1-picrylhydrazyl radical) activity according to [17] with slight modifications. The working solution $(0.04 \mathrm{mmol})$ was prepared by diluting the stock solution with methanol. Filtrates with different concentrations were prepared for all the selected strains. The $100 \mu \mathrm{l}$ of $0.4 \mathrm{mmol}$ DPPH was added to each well containing 50 $\mu \mathrm{l}$ of the filtrate and incubated for $30 \mathrm{~min}$ in the dark, reading was recorded at $517 \mathrm{~nm}$ using a multimode reader (Multiskan Go, Japan). Gallic acid (Sigma Chemical Co., St. Louis, MO, USA) was used as a standard. The percentage of the radical scavenging activity (RSA) was calculated based on the following equation:

$$
\text { DPPH scavenged }(\%)=\frac{A_{(\text {control) }}-A_{(\text {sample })}}{A_{(\text {control })}} \times 100
$$

( $\mathrm{A}_{\text {control }}$ and $\mathrm{A}_{\text {sample }}$ are the absorbance values for the control and sample, respectively)

\section{Molecular identification}

The isolated strains were identified according to methods described in Bergey's Manual of Determinative Bacteriology [18]. Also, 16S rRNA sequence analysis was performed for the best four potential strains. The selected isolates were identified by amplifying the 16S rRNA gene sequence through PCR (Agilent surecycler 8800, USA) using Taq 2X Master Mix Red PCR kits (Ampliqon, Copenhagen, Denmark) and the universal primer set: $27 \mathrm{~F}$ (5'-AGAGTTTGA-TCMTGGCTC AG-3') and 1492R (5'TACGGYTACCTTGTTACGACTT-3'. PCR samples were purified using a PCR purification kit (Favorgen, Taiwan) and amplicons were sequenced by Eurofins genomics laboratory (Bangalore, India). Partial 16S rRNA gene sequences were compared to the data available in GenBank by BLAST searches of the National Centre for Biotechnology Information (NCBI) database (http://www. ncbi. nlm. nih. gov/blast).

\section{Statistical analysis}

Statistical analyses were performed using the SPSS 19.0 software (SPSS Inc., Chicago, IL, USA). Data were subjected to a one-way ANOVA by Duncan's multiple range tests. $P$ value $<0.05$ was considered statistically significant for all analyses.

\section{RESULTS AND DISCUSSION}

\section{Isolation of potential probiotic bacteria from fermented ragi millet}

Totally 177 strains were isolated from the fermented (water and $5 \%$ starch) ragi millet. More number of colonies was observed in the sample that contained 5\% starch which served as a prebiotic for the probiotic bacteria. For all the isolates, colony morphology, catalase test and Gram staining were carried out. Among the strains, 67 strains showed negative for catalase test and 25 strains were Gram positive. The selected 25 strains were screened for in vitro studies [19].

As probiotics are usually administrated orally, they must have the ability to survive passage through the stomach and small intestine. Therefore, resistance to the bile salt in the small intestine is one of the most important selection criteria for probiotic [20]. Resistance to bile is associated to bile salt hydrolase (BSH), an enzyme that helps in hydrolyzing conjugated bile, thereby reducing its toxic effect [21].

In our study, 25 selected isolates were able to survive in the bile salt after $3 \mathrm{~h}$ of incubation (fig. 1). All the isolates showed significant $(\mathrm{P}<0.05)$ survival rate. The highest survival was observed in RS09 isolate, while the least survival was observed in RS07 isolate. The results also showed the decrease in survival rate with increase in duration of incubation. Similar results were reported by [22]. Several reports on the survival ability of the isolates under stimulated gastric bile juice have been documented supporting the present study [23-25]. 
Tolerance to bile salt

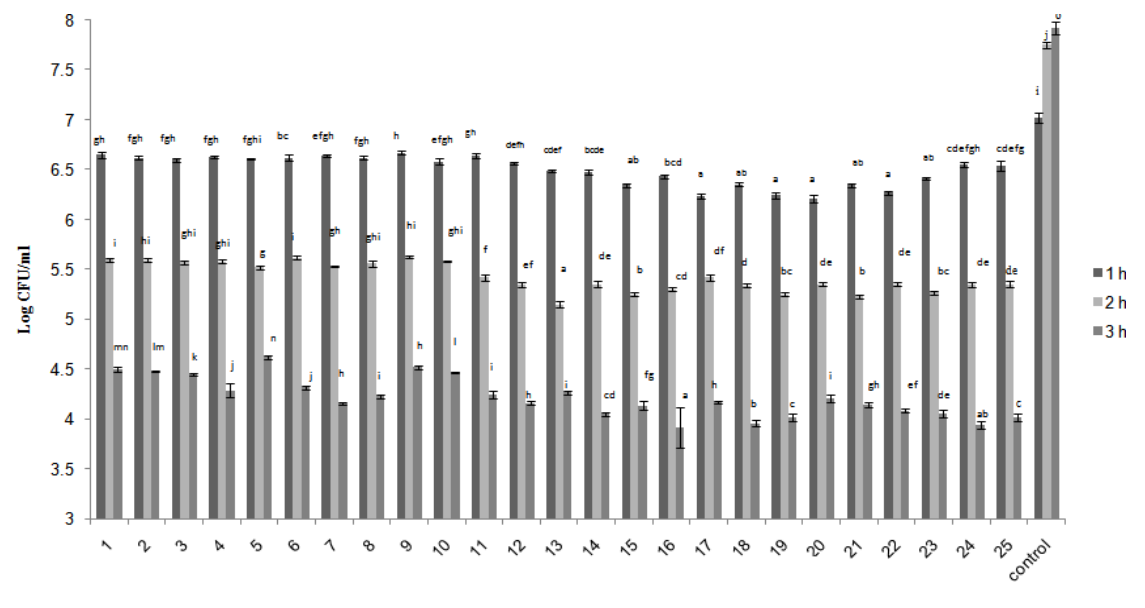

Fig. 1: Viable cell counts of isolates after $3 \mathrm{~h}$ of exposure to $0.3 \%$ bile salt on de Man, Rogosa Sharpe medium, error bar indicates the standard deviation (SD) of three independent experiments.

\section{Tolerance to $\mathrm{pH}$}

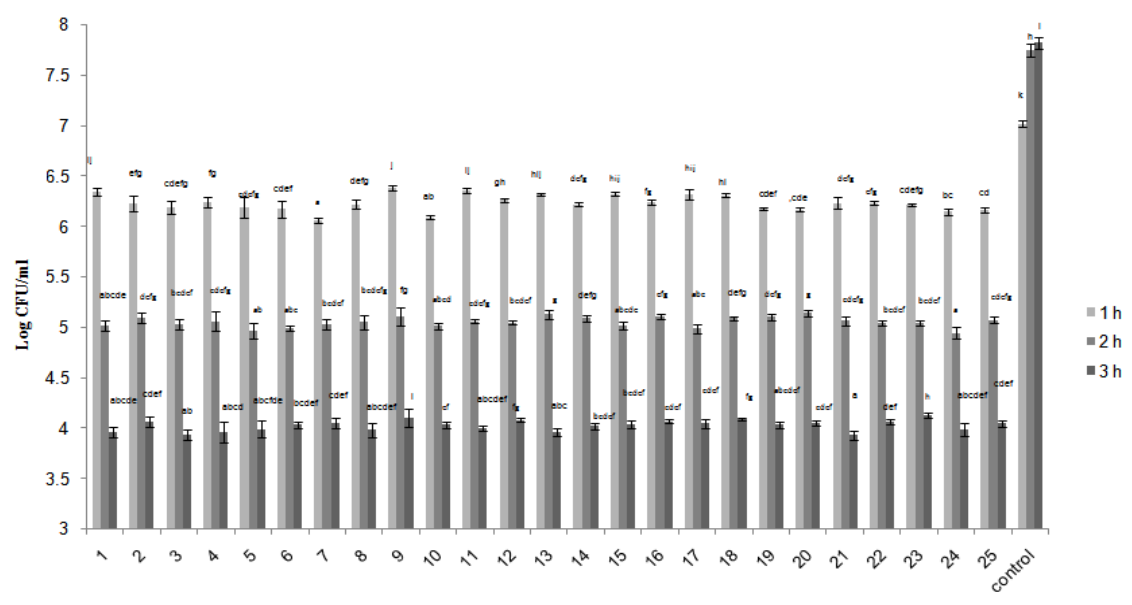

Isolates

Fig. 2: Viable cell counts of isolates after $3 \mathrm{~h}$ of exposure to low $\mathrm{pH} 2.0$ on de medium, error bar indicates the standard deviation (SD) of three independent experiments

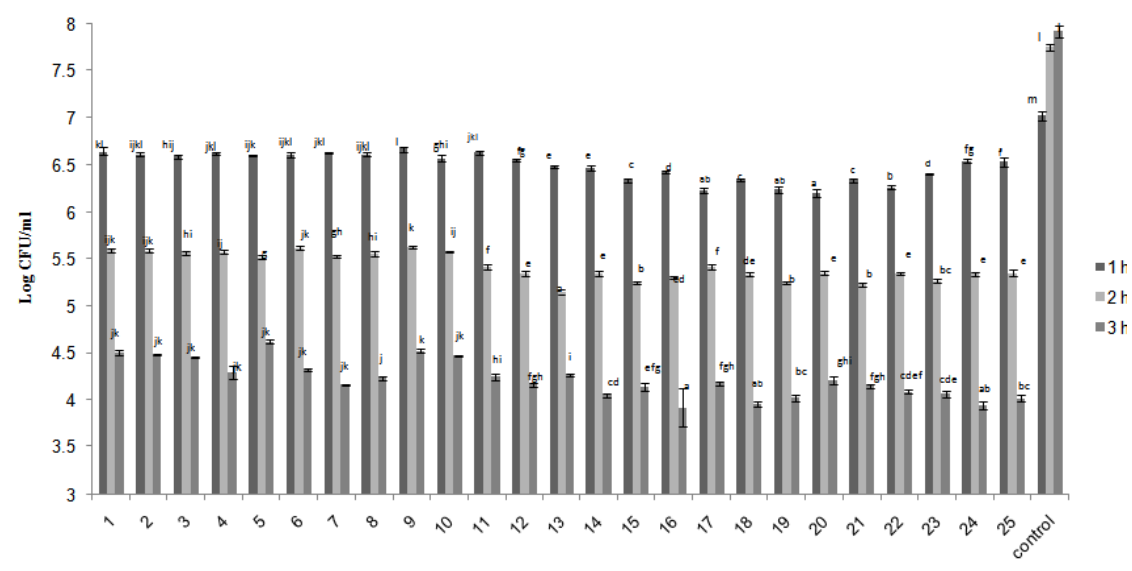

Isolates

Fig. 3: Viable cell counts of isolates after $3 \mathrm{~h}$ of exposure to $\mathrm{pH} 4.0$ on de man rogosa sharpe medium, error bar indicates the standard deviation (SD) of three independent experiments 
A probiotic strain should survive transit through the stomach where the $\mathrm{pH}$ is low around 2 to 4 . Therefore, assessing the tolerance of the isolated strains towards low $\mathrm{pH}$ is an important criterion. Result obtained from the acid tolerance study (fig. 2 and fig. 3 ) indicates that isolates which could not survive in bile salt, also failed to grow at low $\mathrm{pH} 2.0$ whereas showed better survivability at $\mathrm{pH} 4.0$. A similar result was observed and reported by [26]. According to [27], a hydrochloric acid that is found in the human stomach is a strong oxidizer. Thus, it can oxidize many important biomolecular compounds in the cells. Another study concluded that viability count significantly decreased due to the high acidic $\mathrm{pH} 2.0$ environments [12]. Isolates reached the maximum $\mathrm{CFU}$ count with a significant difference $(\mathrm{P}<0.05)$ at $\mathrm{pH} 2$ and 4. Isolate RS19 showed lower and poor tolerance after a subsequent increase in the time duration of 3 $\mathrm{h}$ of incubation. The highest survival was observed in RS09 isolate in both $\mathrm{pH} 2$ and 4.

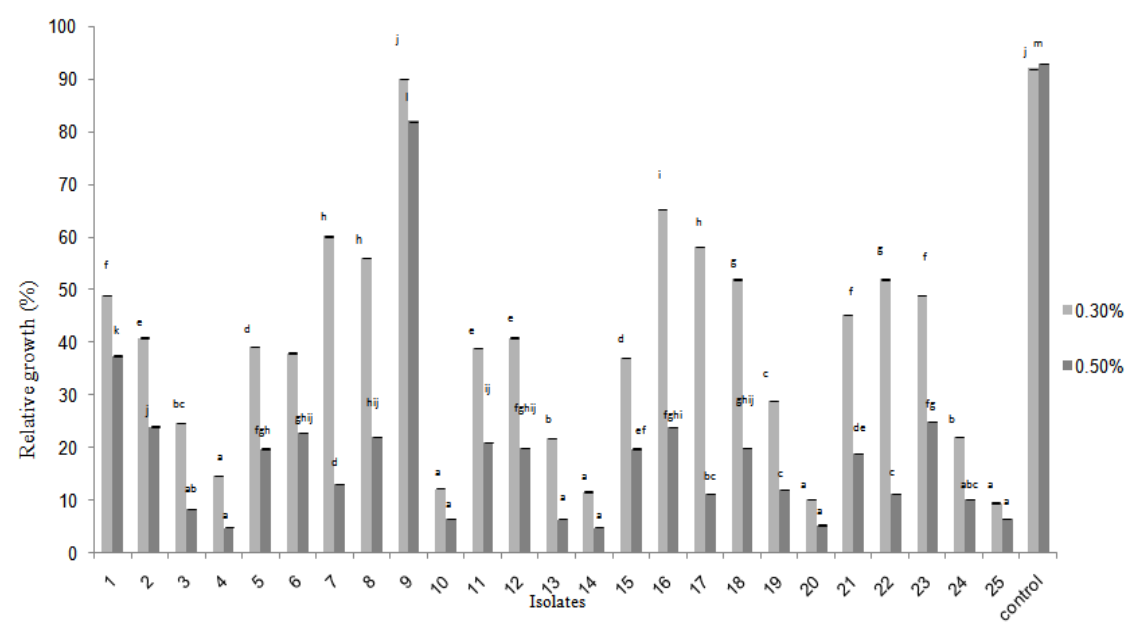

Fig. 4: Survival percentages of isolates after $3 \mathrm{~h}$ of exposure to phenol in de Man, Rogosa Sharpe medium, error bar indicates the standard deviation (SD) of three independent experiments

\section{Phenol tolerance}

Among the twenty-five isolates, RS01, RS09, RS16 and RS23 grew significantly better than other isolates $(\mathrm{P}<0.05)$ in the presence of $0.3 \%$ and $0.5 \%$ phenol concentration than other isolates (fig. 4 ). The isolates RS10, RS20 and RS25 showed less survival rate in the phenolic environment after $3 \mathrm{~h}$ of incubation at $37^{\circ} \mathrm{C}$. The above result is inconsistent with other studies $[13,30]$. Based on the above in vitro tests, best ten isolates were chosen for the antibiotic sensitivity, cholesterol assimilation test and antioxidant activity.

Table 1: Antibiotic sensitivity of the selected isolates according to EFSA (2008)

\begin{tabular}{|c|c|c|c|c|c|}
\hline Isolates & Kanamycin & Gentamicin & Ampicillin & Streptomycin & Erythromycin \\
\hline RS01 & $\mathrm{R}$ & $\mathrm{S}$ & $\mathrm{S}$ & $\mathrm{R}$ & $\mathrm{S}$ \\
\hline RS04 & $\mathrm{S}$ & S & $\mathrm{R}$ & $\mathrm{R}$ & $\mathrm{R}$ \\
\hline RS06 & I & $\mathrm{S}$ & S & $\mathrm{R}$ & $\mathrm{R}$ \\
\hline RS09 & $\mathrm{R}$ & $\mathrm{R}$ & S & $\mathrm{R}$ & $\mathrm{R}$ \\
\hline RS11 & $\mathrm{R}$ & $\mathrm{S}$ & S & $\mathrm{R}$ & $\mathrm{R}$ \\
\hline RS16 & I & I & S & $\mathrm{R}$ & $\mathrm{S}$ \\
\hline RS17 & $\mathrm{S}$ & $\mathrm{S}$ & $\mathrm{R}$ & I & $\mathrm{S}$ \\
\hline RS18 & S & $\mathrm{R}$ & S & $\mathrm{R}$ & $\mathrm{R}$ \\
\hline RS22 & S & $\mathrm{R}$ & $\mathrm{R}$ & $\mathrm{R}$ & $S$ \\
\hline RS23 & $\mathrm{R}$ & $\mathrm{R}$ & $S$ & $\mathrm{R}$ & $\mathrm{R}$ \\
\hline
\end{tabular}

S: Sensitive, I: Intermediate, R: Resistance.

\section{Antibiotic sensitivity test}

All the strains were evaluated for their sensitivity to antibiotics according to the technical guidelines of the European Food Safety Authority [13]. The susceptibility and resistance obtained by the selected isolates against five antibiotics is shown in the Table1. The result obtained indicates that 6 isolates were resistant to most of the antibiotics and sensitive to few antibiotics. According to [28], the antibiotic resistance found in Lactobacillus strains are considered to be intrinsic or natural resistance because it is chromosomally encoded and, therefore, it is non-transmissible. Resistance to antibiotics, such as gentamicin, streptomycin, kanamycin, is also considered to be intrinsic and natural in Lactobacillus genus [29].

\section{Cholesterol assimilation}

The assimilation rates of cholesterol by the isolated strains are shown in fig. 5. The results revealed that all examined strains were able to degrade cholesterol at high levels and also indicate that all of the strains significantly $(\mathrm{P}<0.05)$ decreased the cholesterol level in the medium. Similarly [31], reported that probiotics rich diet significantly decreased the level of cholesterol concentrations in the plasma. Among the tested strains, the degradation rates of the supernatants of RS09 (61.9\%), RS23 (60\%) and RS01 (58.97\%) and RS16 (56.2\%) showed the highest cholesterol assimilation rate. This phenomenon of assimilating cholesterol could be due to the incorporation of cholesterol into the cellular membrane of the organism [32]. 


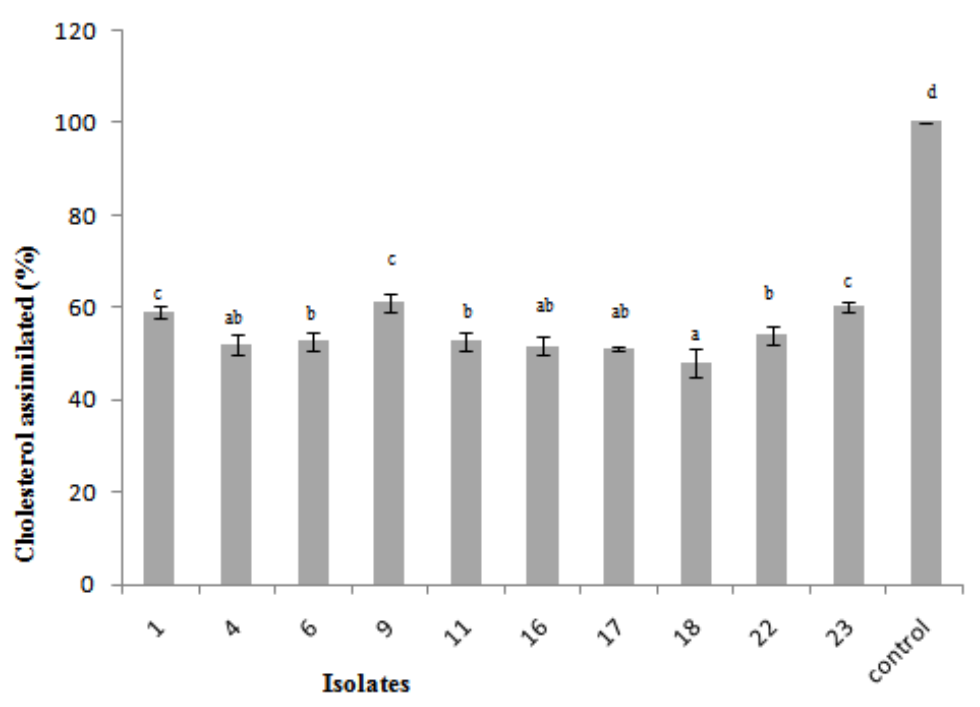

Fig. 5: Cholesterol assimilation rate of isolates in de man rogosa sharpe medium, error bar indicates the standard deviation (SD) of three independent experiments

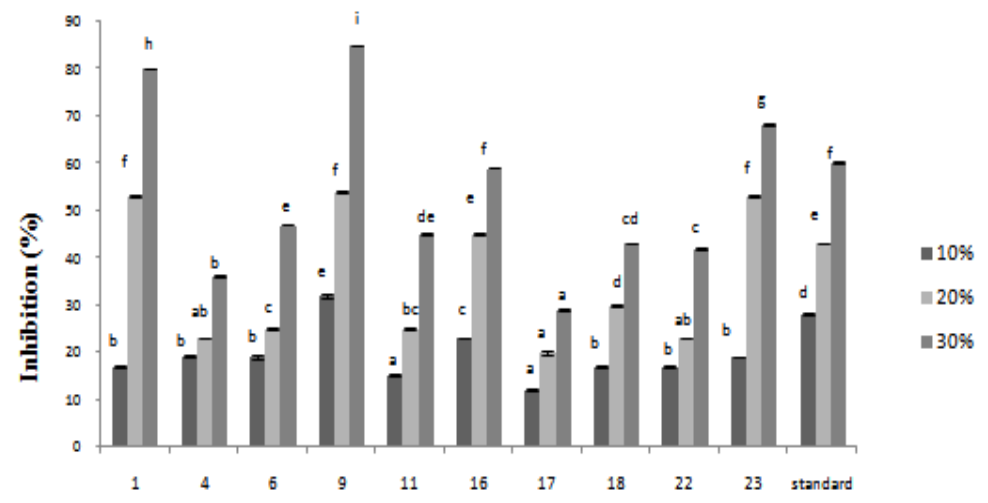

Fig. 6: 2,2-diphenyl-1-picrylhydrazyl radical scavenging activity of selected isolates

\section{Determination of antioxidant activity}

DPPH radical scavenging activities of culture filtrate was evaluated at different concentrations. Isolate RS09 showed the highest antioxidant activity which indicates the strongest ability of the sample to act as DPPH radical scavenger. There were significant differences $(\mathrm{P}<0.05)$ among different strains at different concentrations. Isolate RS17 showed the least inhibition percentage when compared with other isolates. The results of this study are consistent with the observation of [33]. The cell-free extract of the isolates obtained from the fermented millet showed antioxidant activity depending on the strain [34]. The antioxidant activity is concluded to be due to the hydrogen donating ability of the isolates and this can be visually noticed by the change from purple to yellow colour after 30 min of incubation in dark [35].

\section{Molecular identification of potential isolates}

Pure cultures of potential probiotic isolates were grown until log phase and genomic DNA were isolated [36, 37]. Molecular methods are important for bacterial identification [38-41] and possibly more accurate for lactic acid bacteria than the conventional phenotypic methods. The genomic DNA from promising isolates was amplified and sequenced for identification. The amplification of 16S rRNA gene was done by using universal bacterial primer $27 \mathrm{~F}$ (5'AGAGTTTGATCMTGGCTC AG-3') and 1492R (5'-TACGGYTACCTTGTTACGACTT-3') according to the conditions by [42]. The PCR product was sequenced. The sequences were compared with those from GenBank using the BLAST program [43], aligned using the ClustalW software $[44,45]$. The four best potential isolates were found to be Lactococcus lactis RS01, Lactobacillus plantarum RS09, Lactobacillus plantarum RS16 and Lactobacillus plantarum RS23.

\section{CONCLUSION}

In our study, totally 177 strains were isolated from the fermented ragi millet and only twenty-five isolates were selected based on the catalase test and Gram's staining. And different in vitro tests such as resistance to gastrointestinal conditions $(\mathrm{pH}, 2$ and 4; bile salt, $0.3 \%$; phenol 0.3 and $0.5 \%$ ) were performed and ten best strains were selected. The strains were tested to check for the ability to assimilate cholesterol. Among the isolated strains, identified as L. plantarum RS09 manifested the highest cholesterol removal ability and $L$. plantarum RS23 also showed a higher cholesterol removal of $60 \%$. Accordingly, due to its potential probiotic properties, out of the four selected strains, L. plantarum RS09 and L. plantarum RS23 could be potentially used in functional food and other health products especially where cholesterol reduction in food is the main goal. It is also inferred that strains isolated from the traditionally fermented ragi millet showed antioxidant potential at different levels. This extends the application of probiotics in nutraceuticals with antioxidant potential for many degenerative diseases.

\section{ACKNOWLEDGEMENT}

The author would gratefully acknowledge Prof. C. Muthamizchelvan, Director (Engineering and Technology), and Dr. M. Vairamani, Dean School of Bioengineering, SRM Institute of Science and Technology for providing facilities. 


\section{AUTHORS CONTRIBUTIONS}

All the authors are contributed equally to this work.

\section{CONFLICT OF INTERESTS}

We have no conflict of interest to declare.

\section{REFERENCES}

1. Kunchala R, Banerjee R, Mazumdar SD, Durgalla P, Srinivas $V$, Gopalakrishnan S. Characterization of potential probiotic bacteria isolated from sorghum and pearl millet of the semiarid tropics. Afr J Biotechnol 2016;15:613-21.

2. Ahmend AA. In vitro screening of Lactobacillus species from homemade yogurt for antagonistic effects against common bacterial pathogens. Jordan J Biol Sci 2013;6:211-6.

3. Jood S, Khetarpaul N, Goyal R. Effect of germination and probiotic fermentation on $\mathrm{pH}$, titratable acidity, dietary fibre, $\beta$ Glucan and vitamin content of sorghum-based food mixtures. J Nutr Food Sci 2012;2:164.

4. Chen YS, Liou MS, Ji SH, Yu CR, Pan SF, Yanagida F. Isolation and characterization of lactic acid bacteria from Yantsai-shin (Fermented broccoli stems), a traditional fermented food in Taiwan. J Appl Microbiol 2013;115:125-32.

5. Abdulla AA, Abed TA, Saeed AM. Adhesion, autoaggregation and hydrophobicity of six Lactobacillus strains. Br Microbiol Res J 2014;4:381-91.

6. Suskovic J, Bla`enka Kos, Jasna Begano V, Andreja Lebo Pavunc, Ksenija Habjani, Srecko Mato. Antimicrobial activity-the most important property of probiotic and starter lactic acid bacteria. Biotechnology 2010;48:296-307.

7. Deshmukh PV, Thorat PR. Isolation and extraction of bacteriocins produced by lactic acid bacteria isolated from raw milk samples. Indian Streams Res J 2013;3:1-7.

8. Fuller R. Probiotics in man and animals. J Appl Bacteriol 1989;66:365-78.

9. Catanzaro J, Green L. Microbial ecology and probiotics in human medicine (Part II). Altern Med Rev 1997;2:296-305.

10. O'Riordan K, Andrews D, Buckle K, Conway P. Evaluation of microencapsulation of a Bifidobacterium strain with starch as an approach to prolonging viability during storage. J Appl Microbiol 2001;91:1059-66.

11. Gilliland SE, Staley TE, Bush LJ. Importance in bile tolerance of Lactobacillus acidophilus used as a diatery adjunct. J Dairy Sci 1984;67:3045-51.

12. Suneeti Gore, Anjali Paul, Yashada Bhagwat. Comparative evaluation of commercially available probiotics products. Int J Curr Pharm Res 2017;9:26-30.

13. EFSA. Technical guidance prepared by the panel on additives and products or substances used in animal feed (FEEDAP) on the update of the criteria used in the assessment of bacterial resistance to antibiotics of human or veterinary importance. EFSA J 2008;732:1-15.

14. Danielson AD, Peo ER, Shahani KM, Lewis AJ, Whalen PJ, Amer MA. Anticholesterolemic property of Lactobacillus acidophilus yogurt fed to mature boars. J Anim Sci 1989;67:966-74.

15. Teply M Cistemlekarskekultury. Phara SNTL Nakladatelstvi, Technicke Litertury. In: Starters for fermented milks. Kurmann JA. Ed. IDF Bulletin 1984;227:41-55.

16. Rahman MK. Moazzem Hossain, Mahbubur Rahman SM. Isolation, characterization, and properties study of probiotic lactic acid bacteria of selected yoghurt from Bangladesh. Afr J Microbiol Res 2015;10:23-31.

17. Kuskoski EM, Asuero AG, Troncoso AM, Mancini-Filho J, Fett R. Application of several chemical methods to determine antioxidant activity in fruit pulps. Cienciay Tecnología de Alimentos. Campinas 2005;25:726-32.

18. Holt JG, Krieg NR, Sneath PHA, Staley JT, Williams ST. Bergey's Manual of Determinative Bacteriology. $9^{\text {th }}$ ed. Baltimore: Williams and Wilkins; 1994.

19. James Owusu Kwarteng, Kwaku Tano Debrah, Fortune Akabanda, Lene Jespersen. Technological properties and probiotic potential of Lactobacillus fermentum strain isolated from West African fermented millet dough. BMC Microbiol 2015; 15:261.
20. Shehata MG, El Sohaimy SA, Malak A, El-Sahn Youssef MM. Screening of isolated potential probiotic lactic acid bacteria for cholesterol lowering property and bile salt hydrolase activity. Ann Agric Sci 2016;61:65-75.

21. Krishnamoorthy M, Arjun P. Probiotic and antimicrobial activity of bacteria from fermented toddy of Cocus nucifera. J Acad Indus Res 2012;1:127-31.

22. Hyronimus B, Le Marrec C, Hadj Sassi A, Deschamps A. Acid and bile tolerance of spore-forming lactic acid bacteria. Int J Food Microbiol 2002;61:193-7.

23. Faye T, Tamburello A, Vegarud GE, Skeie S. Survival of lactic acid bacteria from fermented milks in an in vitro digestion model exploiting sequential incubation in human gastric and duodenum juice. J Dairy Sci 2012;95:558-66.

24. Garcia Ruiz A, de Llano DG, Esteban Fernandez A, Requena T, Bartolome B, Moreno Arriba SMV. Assessment of probiotic properties in lactic acid bacteria isolated from wine. Food Microbiol 2014;44:220-5.

25. Turchi B, Mancni S, Fratini F, Pedonese F, Nuvoloni R, Bertelloni F, et al. Preliminary evaluation of probiotic potential of Lactobacillus plantarum strains isolated from Italian food products. World J Microbiol Biotechnol 2013;29:1913-22.

26. Ruby Yadav, Anil K, Puniyaand Pratyoosh Shukla. Probiotic properties of Lactobacillus plantarum RYPR1 from an indigenous fermented beverage raabadi. Front Microbiol 2016;7:1683.

27. Zavaglia AG, Kociubinski G, Perez P, Disalvo E, de Antoni G. Effect of bile on the lipid composition and surface properties of bifidobacteria. J Appl Microbiol 2002;93:794-9.

28. Jicheng Wang, Xiao Dong, Yuyu Shao, Huiling Guo, Lin Pan, Wenyan Hui, et al. Genome adaptive evolution of Lactobacillus casei under long-term antibiotic selection pressures. BMC Genomics 2017;18:320.

29. Danielsen M, Wind A. Susceptibility of Lactobacillus spp. to antimicrobial agents. Int J Food Microbiol 2003;82:1-11.

30. Jena, PK, Trivedi D, Thakore K, Chaudhary H, Giri SS, Seshadri S. Isolation and characterization of probiotic properties of Lactobacilli isolated from rat fecal microbiota. Microbiol Immunol 2013;57:407-41.

31. Guo Zhuang, Xiao-Ming Liu, Qiu Xiang Zhang, Feng Wei Tian, Hao Zhang, He-Ping Zhang, et al. Research advances with regards to clinical outcome and potential mechanisms of the cholesterollowering effects of probiotics. Clin Lipidol 2012;7:501-7.

32. Liong MT, Shah NP. Acid and bile tolerance and the cholesterol removal ability of Lactobacilli strains. J Dairy Sci 2005;88:55-66.

33. Lee BJ, Kim JS, Kang YM, Lim JH, Kim YM, Lee MS, et al. Antioxidant activity and $\gamma$-aminobutyric acid (GABA) content in sea tangle fermented by Lactobacillus brevis BJ20 isolated from traditional fermented foods. Food Chem 2010;122:271-6.

34. Yeong Ji Oh, Jung DS. Evaluation of probiotic properties of Lactobacillus and Pediococcus strains isolated from Omegisool, a traditionally fermented millet alcoholic beverage in Korea. LWT Food Sci Technol 2015;63:437-44.

35. Sun YP, Chou CC, Yu RC. Antioxidant activity of Lactic acid bacteria fermented cheese cabbage. Food Chem 2009;115:912-7.

36. Cheng H, Jiang N. Extremely rapid extraction of DNA from bacteria and yeasts. Biotechnol Lett 2006;28:55-9.

37. Sumi Das Purkhayastha, Bhattacharya MK, Prasad HK, Upadhyaya H, Pal K, Sharma Gd. Antimicrobial activity of Lactobacillus fermentum, a volvo vaginal isolate. Asian J Pharm Clin Res 2015;8:371-2.

38. Drancourt M, Bollet C, Carlioz A, Martelin R, Grayral JP, Raoult D. 16S Ribosomal DNA sequence analysis of a large collection of environmental and clinical unidentifiable bacterial isolates. J Clin Microbiol 2000;38:3623-30.

39. Sghir A, Gramet G, Suau A, Rochet V, Pochart P, Dore J. Quantification of bacterial groups within human fecal microbiota by oligonucleotide probe hybridization. Appl Environ Microbiol 2000;66:2263-6.

40. Greetham HL, Giffard C, Hutson RA, Collins MD, Gibson GR. Bacteriology of the Labrador dog gut: a cultural and genotypic approach. J Appl Microbiol 2002;93:640-6.

41. Heilig HGHJ, Zoetenda EG, Vaughan EE, Marteau P, Akkermans ADL, De Vos WM. Molecular diversity of Lactobacillus ssp. and 
other lactic acid bacteria in the human intestine as determined by specific amplification of $16 \mathrm{~S}$ ribosomal DNA. Appl Environ Microbiol 2002;68:114-23.

42. Pandey P, Kang SC, Maheswari DK. Isolation of endophytic plant growth-promoting Burkholderia spp. MSSP from root nodules of Mimosa pudica. Curr Sci 2005;89:177-80.

43. Alschul SF, Gish W, Miller W, Myers EW, Lipman DJ. Basic local alignment search tool. J Mol Biol 1990;215:403-10.
44. Thompson JD, Gibsom TJ, Plewnaik F, Jeanmougin F, Higgins DG. The clustalX windows interface: flexible strategies for multiple sequence alignment aided by quality analysis tools. Nucleic Acids Res 1997;24:4876-82.

45. Hemal Sadrani, Jayantilal Dave, Bharatkumar Rajiv Manuel Vyas. Screening of potentially probiotic Lactobacillus strains isolated from fermented foods, fruits and of human origin. Asian J Pharm Clin Res 2014;7 Suppl 2:216-25. 